\title{
EVALUATION AND FORECAST OF HUMAN IMPACTS BASED ON LAND USE CHANGES USING MULTI-TEMPORAL SATELLITE IMAGERY AND GIS: A CASE STUDY ON ZANJAN, IRAN (1984-2009)
}

\author{
Mohsen Ahadnejad *a, Ali Reza Rabet ${ }^{\mathrm{b}}$ \\ ${ }^{\text {a }}$ Assistance Professor, Dept. of Geography, Zanjan University, Iran- E-mail :ahadnejad@gmail.com \\ ${ }^{\mathrm{b}}$ PhD student in Geography and Rural planning, Peyam-e-Nour University, Tehran Branch- E-mail :Rabet2001IRAN@yahoo.com
}

Key Words :Fuzzy ARTMAP, Cellular Automata, Markov Chain, Land-use Change Detection

\begin{abstract}
:
Land use and land cover change due to human activities in a time sequence .Detection of such changes may help decision makers and planners to understand the factors in land use and land cover changes in order to take effective and useful measures . Remote sensing and GIS techniques may be used as efficient tools to detect and assess land use changes.

In recent years, a considerable land use changes have occurred in the greater Zanjan area .In order to understand the type and rate of changes in this area, Landsat TM images captured in 1984 and 2009 have been selected for comparison.

First, geometric correction and contrast stretch are applied .In order to detect and evaluate land use changes, image differencing, principal component analyses and Fuzzy ARTMAP classification method are applied .Finally, the results of land cover classification for three different times are compared to reveal land use changes.Then, combined Cellular Automata with Markov Chain analysis is employed to forecast of human impacts on land use change until 2020 in Zanjan area

The results of the present study disclose that about 36 percents of the total area changed their land use, e.g., changing agricultural land, orchard and bare land to settlements, construction of industrial areas and highways .The crop pattern also changes, such as orchard land to agricultural land and vice versa. The mentioned changes have occurred within last 25 years in Zanjan city and its surrounding area.
\end{abstract}

\section{Introduction:}

The protection of global environment is one of the most critical problems and it is related to several factors, such as population increase, depletion of natural resources, environmental pollution and land use planning.Presently unplanned changes of land use have become a major problem .Most of the land use changes occur without clear and logical planning, paying no attention to their environmental impacts.Floods and air pollution in large cities as well as deforestation, urban growth, soil erosion and desertification are all consequences of mismanaged planning without considering environmental impacts.

Many researchers have employed satellite imagery for land use mapping as well as change detection .Sunarar (1998) has compared the results of five different techniques :band combination, subtraction, band division, principal component analysis and classification, in Ekitally, Turkey.This study revealed that the principal component analysis (PCA) shows better results comparing with classification results . Gupta and Parakash (1998) used a combined method of colour composite, band subtraction, band division and supervised classification to prepare a land-use map for change detection in a coal-mining district in India.They concluded that the supervised classification gives better results for detecting changes .Ahandejad (2002) used PCA, image differencing and classification methods for change detection in Maragheh region, Iran .He concluded that a crosstab method and a comparison image classification method are very suitable for land use change assessment.Neshat (2002) employed Markov Chain to detect the change of forest areas to urban use in Golestan province, Iran .
In the present research, supervised classification based on Fuzzy Artmap is employed to detect land use changes occurred in the Zanjan area, Iran .For forecasting human impacts on land-use change until 2020, both Cellular Automata and Markov Chain are employed.

\section{Study Area and Methods of Study:}

The study area is located between $36^{\circ} 38^{\prime} 56^{\prime \prime}$ to $36^{\circ} 42^{\prime} 22^{\prime \prime}$ $\mathrm{N}$ and $48^{\circ} 25^{\prime} 42^{\prime \prime}$ to $48^{\circ} 33^{\prime} 05^{\prime \prime} \mathrm{E}$. The area covers Zanjan city and its surrounding area with 7180 hectares .The study area comprises two topographic units' foothill and plain . Zanjan population in 1986 was about 215,458 people and its population has been reached to 349,713 people in 2006 , the population growth rate in this period was about 3.93 percent . The main reason to select this area is that considerable land-use changes have occurred due to urban developments, rural developments, and industrial developments in the east, west and south areas, and that major changes in the crop pattern are ongoing.

\section{Material and methods:}

In this paper, Landsat TM images captured in 1984 and 2009 are employed for digital image processing .Figure 1 shows Landsat TM image were used in this study. Also Figure 2 shows the flowchart of this study.

\footnotetext{
*- Corresponding author
} 


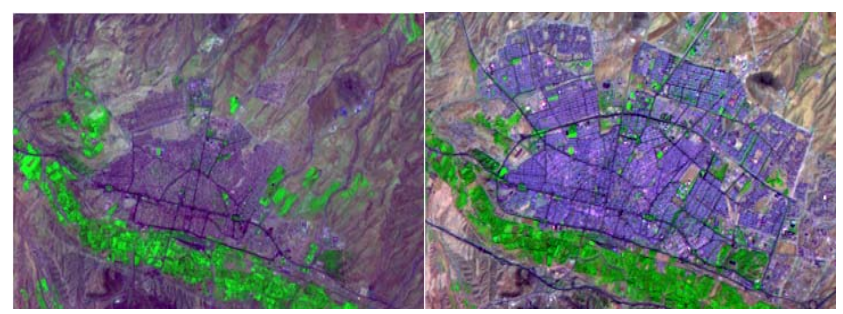

Figure1 .Landsat TM image from case study area in 1984(left) and 2009(right)

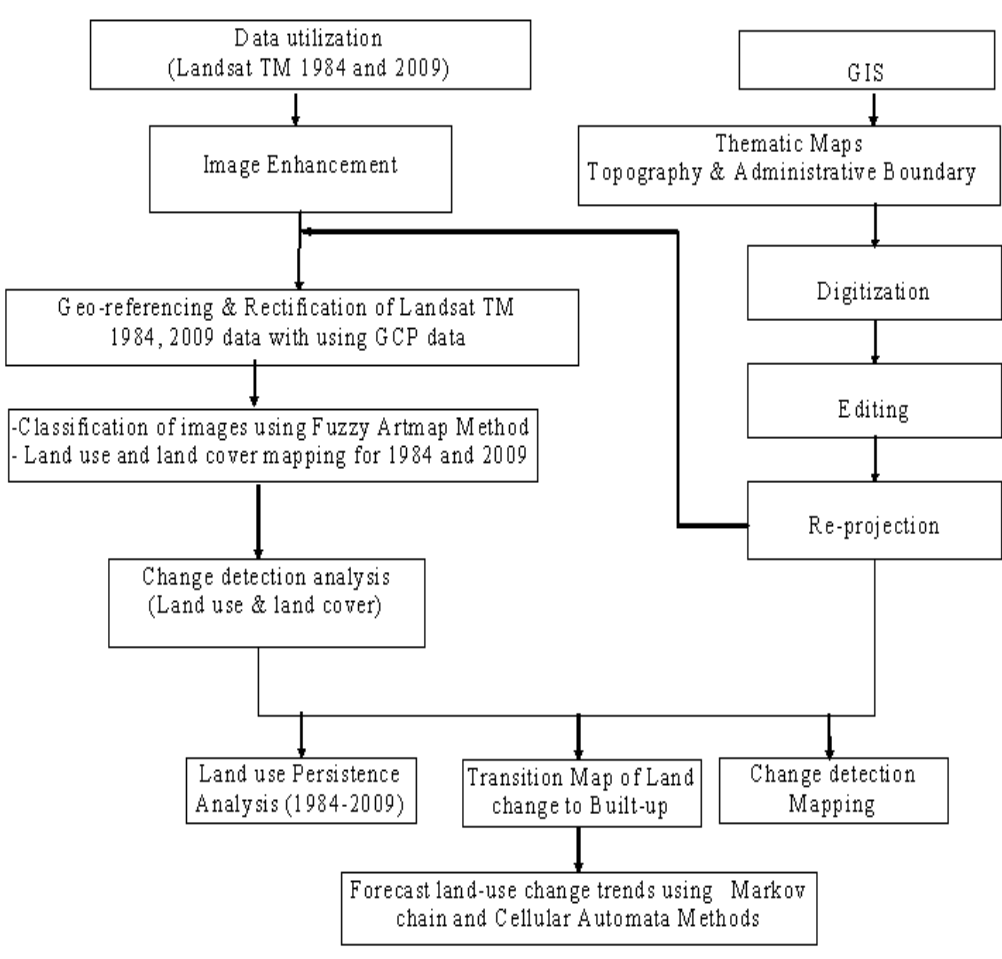

Figure 2 . Flow chart showing the major steps of this research

\section{Classification:}

Various methods have been employed for classification of satellite imagery .Recently, artificial fuzzy methods are used widely because they show very high accuracy in comparison with the conventional ones like Maximum Likelihood Classification (MLC), Minimum Distance Classification, and Parallelepiped Classification.

In this paper, the fuzzy adaptive resonance theory (Fuzzy Artmap( is employed for image classification. First, 741 RGB color composites of Landsat images were prepared .Then, training areas were selected for 6 land use and Land cover classes, which are built-up area, orchards, irrigated agriculture land, dry farming, water, regolith and waste land . These training areas were determined, referring to aerial photographs and GIS thematic maps. To assess the accuracy of classification, topographic maps and aerial photos were employed .Overall accuracy was estimated to be around $96 . \%$ Figures 3 and 4 shows the results of land use classification and Table 1 shows the summary of the classification.

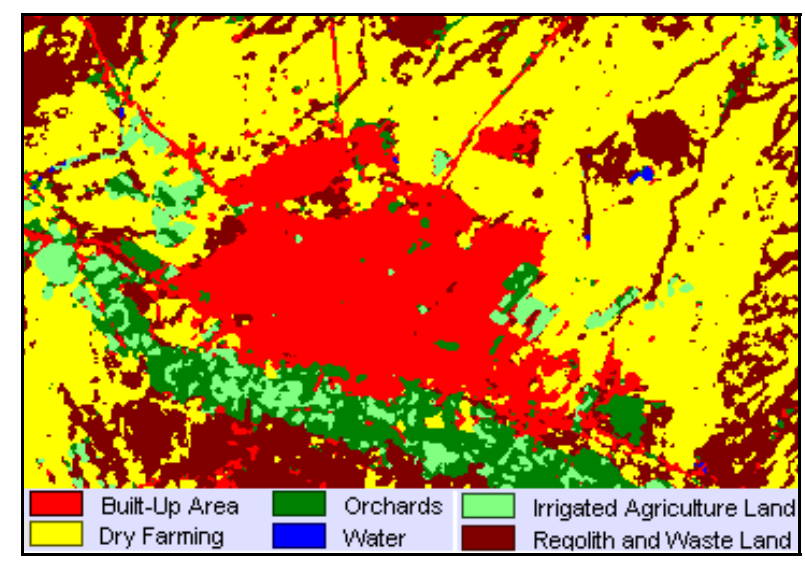

Figure 3 :Result of land use classification for Zanjan, Iran using Landsat TM image captured in 1984

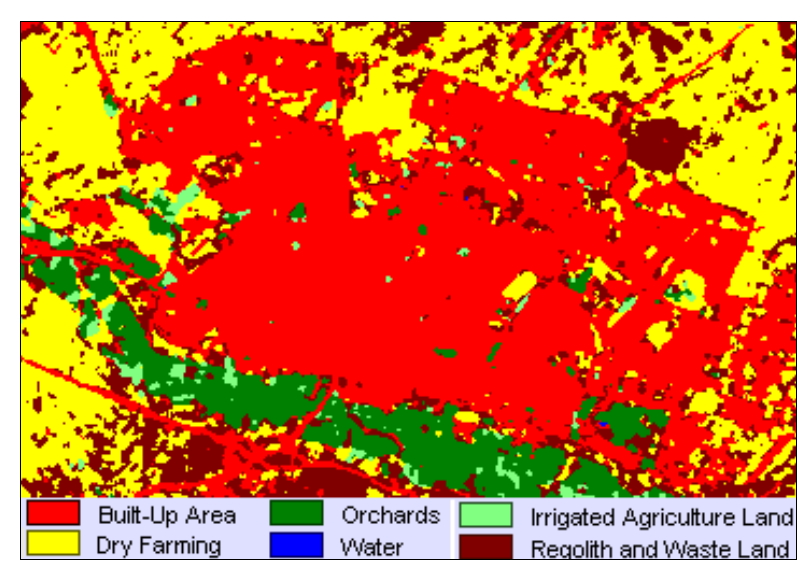

Figure 4 .Result of land use classification using Landsat ETM + image captured in 2009

\begin{tabular}{|c|c|c|c|}
\hline Class & Land use Type & 1984 & 2009 \\
\hline 1 & Built-Up Area & 1417.06 & 3377.88 \\
\hline 2 & Dry Farming & 3355.60 & 1987.65 \\
\hline 3 & Orchards & 614.12 & 609.21 \\
\hline 4 & Water & 2.14 & 0.9 \\
\hline 5 & $\begin{array}{c}\text { Irrigated Agriculture } \\
\text { Land }\end{array}$ & 355.65 & 124.65 \\
\hline 6 & $\begin{array}{c}\text { Regolith and Waste } \\
\text { Land }\end{array}$ & 1435.72 & 1080 \\
\hline & Total-Hectare & 7180.29 & 7180.29 \\
\hline
\end{tabular}

Table 1 .Summary of image classification performed in this study(Hectare)

\section{Comparison of classification results:}

The classification results for the two different times revealed that the land use of the target area has changed about $36 \%$ during the period of 1984-2009. Table 2 shows the estimated land use transitions based on the comparison of the classification results for the 1984 and 2009 images .Figure 4 shows the areas whose land use has changed to built-up ones in these periods .More than $60 \%$ of the area that belongs to built-up changes to dry farming and waste areas .Dry land farming attains the least changes $27.68 \%$ in this period . 
The results also show that built-up area changed from 1417.06 hectare in 1984 to 3377.88 hectare in 2009 . The increase is mainly due to the needs of settlements in Zanjan City because its population has increased from 215,458 in 1986 to 349,713 in 2006 .New suburban areas, such as Sayan, Elahieh,Amir Kabir,GolShahr and Kazemieh, have also developed in the period.

\begin{tabular}{|c|c|c|c|c|c|c|c|c|}
\hline $\begin{array}{l}\text { Land } \\
\text { use\& } \\
\text { Land } \\
\text { Cover }\end{array}$ & $\begin{array}{l}\text { Built-U } \\
\text { p Area }\end{array}$ & $\begin{array}{c}\text { Dry } \\
\text { Farmin } \\
\mathrm{g}\end{array}$ & $\begin{array}{l}\text { Orch } \\
\text { ard }\end{array}$ & $\begin{array}{l}\text { Wa } \\
\text { ter }\end{array}$ & $\begin{array}{c}\text { Irrigated } \\
\text { Agricultur } \\
\text { e Land }\end{array}$ & $\begin{array}{c}\text { Regolith } \\
\text { and Waste } \\
\text { Land }\end{array}$ & $\begin{array}{c}\text { Tota } \\
1\end{array}$ & $\begin{array}{c}\text { Chan } \\
\text { ge }\end{array}$ \\
\hline $\begin{array}{c}\text { Built-Up } \\
\text { Area }\end{array}$ & $\begin{array}{c}1417.0 \\
6\end{array}$ & 0 & 0 & $\begin{array}{c}0.5 \\
4 \\
\end{array}$ & 0 & 0 & $\begin{array}{c}1476 \\
.27\end{array}$ & 20 \\
\hline $\begin{array}{c}\text { Dry } \\
\text { Farming }\end{array}$ & $\begin{array}{c}1444.3 \\
2\end{array}$ & $\begin{array}{c}1380.0 \\
6\end{array}$ & $\begin{array}{c}30.3 \\
3\end{array}$ & $\begin{array}{c}0.2 \\
7\end{array}$ & 27.54 & 448.74 & $\begin{array}{c}3331 \\
.26\end{array}$ & $\begin{array}{c}46.3 \\
9\end{array}$ \\
\hline Orchards & 21.15 & 107.19 & $\begin{array}{c}384 . \\
93 .\end{array}$ & 0 & 27.27 & 69.12 & $\begin{array}{c}609 . \\
66\end{array}$ & 8.48 \\
\hline Water & 2.7 & 3.6 & 0 & 0 & 0 & 2.25 & 8.55 & 0.1 \\
\hline $\begin{array}{l}\text { Irrigated } \\
\text { Agricultu } \\
\text { re Land }\end{array}$ & 57.51 & 37.26 & $\begin{array}{c}161 . \\
28\end{array}$ & 0 & 58.68 & 38.34 & $\begin{array}{c}353 . \\
07\end{array}$ & 4.92 \\
\hline $\begin{array}{l}\text { Regolith } \\
\text { and } \\
\text { Waste } \\
\text { Land }\end{array}$ & 376.47 & 459.54 & $\begin{array}{c}32.6 \\
7\end{array}$ & $\begin{array}{c}0.0 \\
9\end{array}$ & 11.16 & 521.55 & $\begin{array}{c}1401 \\
.48\end{array}$ & $\begin{array}{c}19.5 \\
2\end{array}$ \\
\hline Total & $\begin{array}{c}3377.8 \\
8 \\
\end{array}$ & $\begin{array}{c}1987.6 \\
5\end{array}$ & $\begin{array}{c}609 . \\
21\end{array}$ & 0.9 & 124.65 & 1080 & $\begin{array}{c}7180 \\
.29 \\
\end{array}$ & \\
\hline Change & 47.04 & 27.68 & 8.48 & 0.0 & 1.74 & 15.04 & & 100 \\
\hline
\end{tabular}

Table 2 .Estimated land use transitions in Zanjan area between 1984 and 2009 (Hectare)

\section{Analysis of Land use Transition to Built-Up Area}

The Results of Land use changes analysis show that in case study area dry farming and regolith and waste land have most change to built-up area that respectively 1444.32 and 376.47 hectares .Also water body and orchards have minimum changes to built-up area that respectively 2.7 and 21.15 hectares .

In totally in Land use and Land cover changes in 1984-2009, Built-up area have maximum changes with 47.04 percent and minimum changes related to water body with 0.01 percent changes. Figure 5 show the areas that have changed to built-up ones in the period of 1984-2009.

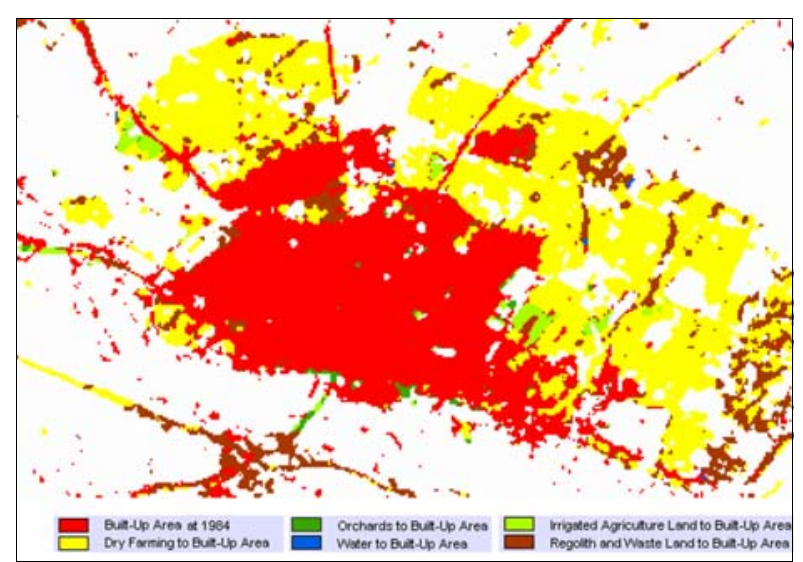

Figure 5 .The areas that have changed to built-up ones in the period of 1984-2009

\section{Land use Persistence and Changes Analysis}

One of other analysis in this paper related to land use persistence in the period of 1984-2009 in our case study .It means that how much of land use and land cover and what areas have persistence in during of study periods and has not changes. According to analysis in this case study area about 3848.87 hectares of land use and land cover have not any changes and 3383 hectare of land use and land cover has been changed in the study period 1984-2009.
In between land use built-up area with 1486 hectare has most persistence in comparing with another land use and Irrigated Agriculture Land with 59 hectare has lowest persistence in our case study area .Also dry farming with 1961.6 hectare has maximum changes and orchards with 223.38 hectare have minimum changes in Zanjan area between 1984 and 2009 . Table 3 and figure 6 and 7 shows that spatial distribution map of land use and land cover persistence and Land use changes in the period of 1984-2009.

\begin{tabular}{|c|c|c|c|}
\hline ID & Type & Persistence & Changes \\
\hline 1 & Built-Up Area & 1417.51 & 0.00 \\
\hline 2 & Dry Farming & 1390.14 & 1961.60 \\
\hline 3 & Orchards & 387.74 & 223.38 \\
\hline 5 & $\begin{array}{c}\text { Irrigated Agriculture } \\
\text { Land }\end{array}$ & 59.11 & 291.54 \\
\hline 6 & $\begin{array}{c}\text { Regolith and Waste } \\
\text { Land }\end{array}$ & 525.36 & 907.36 \\
\hline & Total & 3779.87 & 3383.88 \\
\hline
\end{tabular}

Table 3 .Estimated land use persistence and changes in Zanjan Area between 1984 and 2009

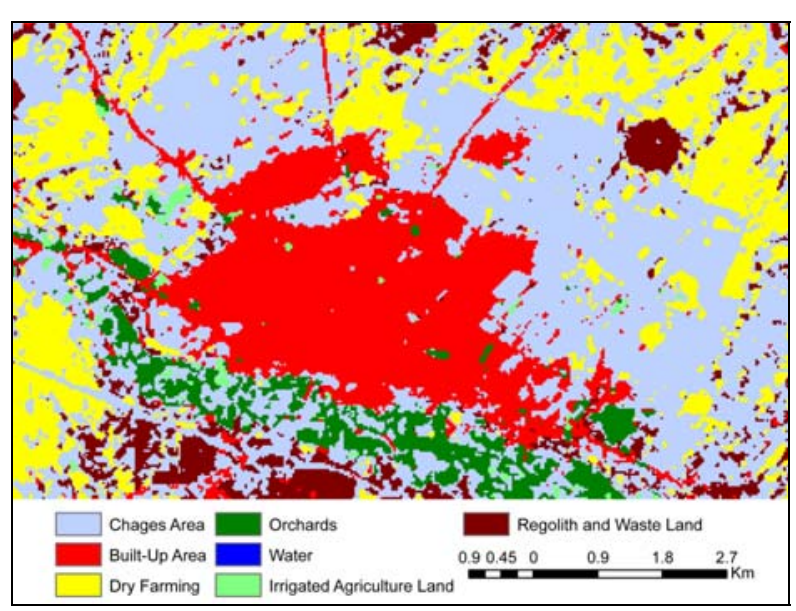

Figure 6 .The areas have that Land use persistence between $1984-2009$

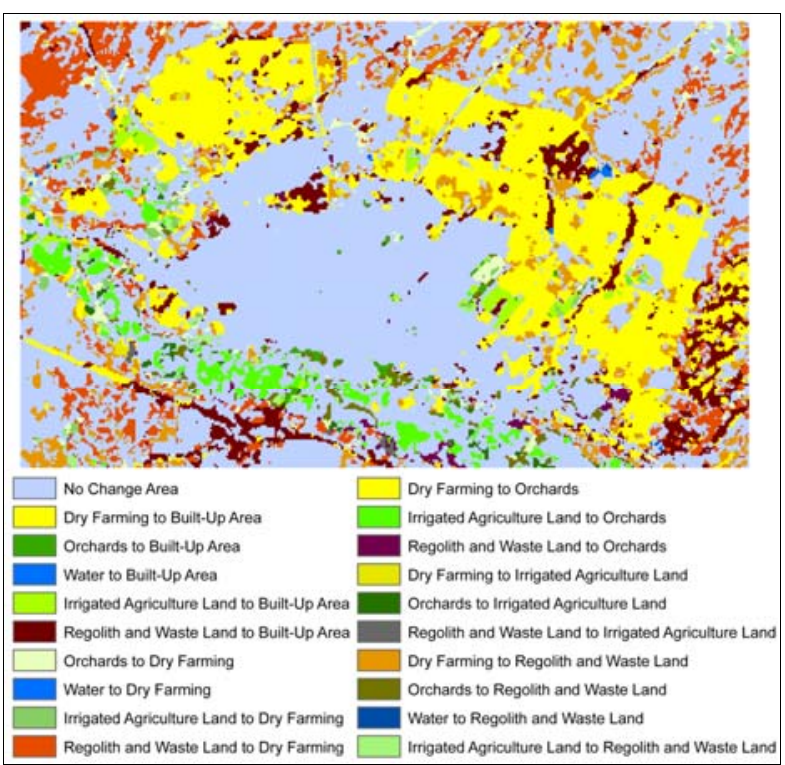

Figure 7.The areas have that Land use changes between $1984-2009$ 
8.Prediction of the trends of land use changes :

The other object of this paper is to predict the trend of land use changes in the future .Many methods can be applied to predict the trend .In this paper, two methods are used.

\subsection{Markov chain}

The Markov chain method analyzes a pair of land cover images and outputs a transition probability matrix, a transition area matrix, and a set of conditional probability images .The transition probability matrix shows the probability that one land-use class will change to the others . The transition area matrix tells the number of pixels that are expected to change from one class to the others over the specified period.

The conditional probability images illustrate the probability that each land cover type would be found after a specific time passes .These images are calculated as projections from the two input land cover images. The output conditional probability images can be used as direct input for specification of the prior probabilities in Maximum Likelihood Classification of remotely sensed imagery (such as with the MAXLIKE and BAYCLASS modules).A raster group file is also created listing all the conditional probability images.

In this study, a series of image processing was performed to predict the trend of land use change in 2020 (Table 4). The result shows that the probability to change to Built-up area is highest .Figure 8 shows the probability that the area will be converted to Build-up area in 2020.

\begin{tabular}{|c|c|c|c|c|c|c|}
\hline & $\begin{array}{c}\text { Built-Up } \\
\text { Area }\end{array}$ & $\begin{array}{c}\text { Dry } \\
\text { Farming }\end{array}$ & Orchards & Water & $\begin{array}{c}\text { Irrigated } \\
\text { Agriculture } \\
\text { Land }\end{array}$ & $\begin{array}{c}\text { Regolith } \\
\text { and } \\
\text { Waste } \\
\text { Land }\end{array}$ \\
\hline $\begin{array}{c}\text { Built-Up } \\
\text { Area }\end{array}$ & 0.9998 & 0 & 0 & 0.0002 & 0 & 0 \\
\hline $\begin{array}{c}\text { Dry } \\
\text { Farming }\end{array}$ & 0.2715 & 0.5708 & 0.0024 & 0 & 0.0094 & 0.1458 \\
\hline Orchards & 0 & 0.1072 & 0.7806 & 0 & 0.0411 & 0.0711 \\
\hline Water & 0.1297 & 0.53 & 0 & 0 & 0 & 0.3403 \\
\hline $\begin{array}{c}\text { Irrigated } \\
\text { Agriculture } \\
\text { Land }\end{array}$ & 0.1027 & 0.0372 & 0.4981 & 0 & 0.2724 & 0.0896 \\
\hline $\begin{array}{c}\text { Regolith } \\
\text { and Waste } \\
\text { Land }\end{array}$ & 0.0978 & 0.3549 & 0.0163 & 0 & 0.0071 & 0.5238 \\
\hline
\end{tabular}

Table 4 .The probability of land use changes based on Markov Chain in the period of 2009-2020

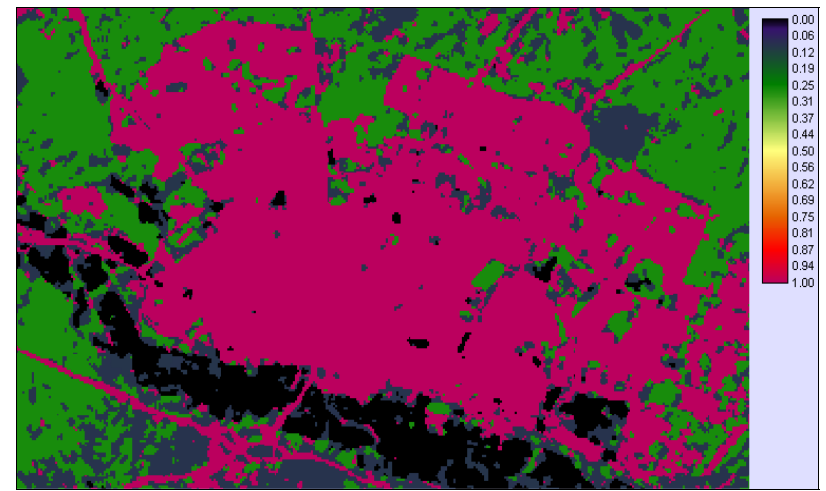

Figure 8 .The probability to remain/change to built-up areas by 2020 obtained by Markov Chain

8.2 Combination of Cellular Automata and Markov Chain
To know the changes that have occurred in the past may help to predict future changes .Combination of Cellular Automata and Markov Chain is often employed to predict land cover change estimation

In order to predict the trends of land use changes, first 1984 and 2009 land use map were analyzed with Markov Chain . Then, combined method of Cellular Automata and Markov Chain was used for forecasting land use change in 2020 . According to the results (Figure 9 and Table 5), built-up areas increase from 3377.88 hectare in 2009 to 4034.79 hectare in 2020 and the probability that the areas will change to built-up one is highest .

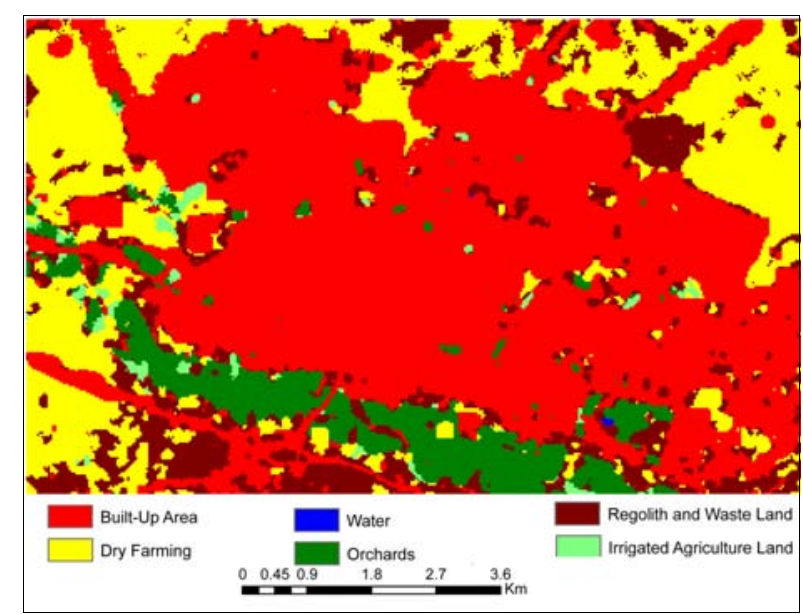

Figure 9 .Predicted result of land-use change in 2020 by the combination of Cellular Automata and Markov Chain

\begin{tabular}{|c|c|c|c|c|c|c|}
\hline & $\begin{array}{c}\text { Built-Up } \\
\text { Area }\end{array}$ & $\begin{array}{c}\text { Dry } \\
\text { Farming }\end{array}$ & Orchards & Water & $\begin{array}{c}\text { Irrigated } \\
\text { Agriculture } \\
\text { Land }\end{array}$ & $\begin{array}{c}\text { Regolith } \\
\text { and } \\
\text { Waste } \\
\text { Land }\end{array}$ \\
\hline $\begin{array}{c}\text { Built-Up } \\
\text { Area }\end{array}$ & 0.9998 & 0 & 0 & 0.0002 & 0 & 0 \\
\hline $\begin{array}{c}\text { Dry } \\
\text { Farming }\end{array}$ & 0.2715 & 0.5708 & 0.0024 & 0 & 0.0094 & 0.1458 \\
\hline Orchards & 0 & 0.1072 & 0.7806 & 0 & 0.0411 & 0.0711 \\
\hline Water & 0.1297 & 0.53 & 0 & 0 & 0 & 0.3403 \\
\hline $\begin{array}{c}\text { Irrigated } \\
\text { Agriculture } \\
\text { Land }\end{array}$ & 0.1027 & 0.0372 & 0.4981 & 0 & 0.2724 & 0.0896 \\
\hline $\begin{array}{c}\text { Regolith } \\
\text { and Waste } \\
\text { Land }\end{array}$ & 0.0978 & 0.3549 & 0.0163 & 0 & 0.0071 & 0.5238 \\
\hline
\end{tabular}

Table 5 . The result of prediction of land use in 2020 by the combination of Cellular Automata and Markov Chain

\section{Conclusions :}

In this paper, using Landsat Satellite images in 1984 and 2009, land use changes in Zanjan city area, Iran were evaluated.For classification of the images, Fuzzy Artmap classification method was applied, which has very high confidence comparing with other classification methods .In addition, combined Cellular Automata with Markov Chain method was employed to forecast human impacts on land use change until 2020 for the study area.

The results revealed that the land use change has occurred for the area of about 3383.88 hectares in the period 1984-2009. These changes due to developments of settlements on orchards and agriculture lands, which occurred mostly in the urban fringe of Zanjan city, are recognized as highly impacted areas from the environmental point of view.

According to Cellular Automata and Markov Chain Forecasting model, built-up areas will increase from 3377.88 
hectare in 2009 to 4034.79 hectare in 2020 . The continuation of such a trend may endanger the surrounding land as well as the agricultural lands and orchards in the area .Hence, it is recommended to protect these critical areas.

The results of this study also revealed that agricultural land around major towns and settlements are recognized as critical regions in terms of land use changes, and special protection measures are needed to be taken.In case of improper planning, these regions will be changed to settlements in a very short time, which is totally in contradiction to sustainable development.

\section{References}

Ahadnejad, M ,2002 .Environmental land use Chang detection and assessment using with multi -temporal satellite imagery, Mapasia2002, Bangkok, Thailand.

Carpenter, G.A., Grossberg, S., and Reynolds, J.H ,1991. ARTMAP :Supervised Real-Time Learning and Classification of Non stationary Data by a Self-Organizing Neural Network .Neural Networks, 4, 565-588.

Carpenter, G.A, 1989 .Neural Network Models for Pattern Recognition and Associative Memory .Neural Networks, 2, 243-257.

Eastman, J .Ronald, 2006 .IDRISI Andes Tutorial .Clark Labs .Clark University.

Gong, P, 1993 .Change Detection Using Principal Component Analysis and Fuzzy Set Theory, Can , J . Remote Sensing .19(1)22-29.

Jensen, J.R, 1996 .Introduction to Digital Image Processing :A Remote Sensing Perspective, Englewood Cliffs, New Jersey :Prentice-Hall.

Muchoney, D .and J .Williamson, 2001 .A Gaussian Adaptive Resonance Theory Neural Network Classification Algorithm Applied to Supervised Land Cover Mapping Using Multi Temporal vegetation Index Data, IEEE Transaction September .

Neshat, A, 2002 .Analysis and evaluation land use and land-cover changes using remote sensing data and geographic information systems in Golestan province, Msc Thesis, Tarbat Modaress University, Tehran, Iran.

Pontius, Jr, Robert Gilmore, Olufunmilayo Thontteh and Hao Chen, 2008 .Land Change Modeling with GEOMOD, Clark University .

Prakash, A and Gupta, R .P, 1998 .Land use mapping and change detection in a coal mining area, a case study in the Jharia coalfield, India", Int .J .Remote sensing Vol .19.

Stehman, S.V, 1996 .Estimating the Kappa Coefficient and Its Variance under Stratified Random Sampling . Photogrammetric Engineering and Remote Sensing .62, 401, 407.

Sunar, F, 1998 .An Analysis of changes in a Multi -data set; a case study in the Ikitelli area Istanbul Turkey, Int, J, Remote Sensing, Vol.19 .
Tung-Hsu Tong HOU and Ming-Der Pern, 2000 .A New Shape Classifier by Using Image Projection and a Neural Network, International Journal of Pattern Recognition and Artificial Intelligence, Vole 14, NO.2. 